\title{
Introduction to the Special Issue: Towards a theoretical understanding of innovation and entrepreneurship in India
}

\author{
Sanjay Jain ${ }^{1}$ - Anil Nair ${ }^{2} \cdot$ David Ahlstrom ${ }^{3}$ \\ Published online: 14 November 2015 \\ (C) Springer Science+Business Media New York 2015
}

Over the past few decades, India has become one of the world's most vibrant economies (Chari \& Banalieva, 2015). While the first forty years after India's independence in 1947 was characterized by a sluggish annual growth rate (of approximately 3\%), economic reforms initiated in 1991 have resulted in the GDP growing at a rate of around $6.8 \%$ in the last quarter century (Chari \& Banalieva, 2015; McCloskey, 2010). Conversely, while the pre-reform institutional environment generally underemphasized and undermined entrepreneurial and innovative activity (Bardhan, 1994; Baumol, Litan, \& Schramm, 2009; Sivaraman, 1991), the post-reform period has been characterized by a much wider acceptance of the value of innovation and entrepreneurship. Moreover, many Indian firms and entrepreneurs have emerged as global leaders in information technology (IT) services, auto, steel and generic drug production as well as medical services (Chari \& Banalieva, 2015). India's emergence as a significant player in the global business landscape has been accompanied by a boom in discourse about Indian economy and management, with academics, journalists, consultants and managers alike studying and chronicling these in numerous articles and books (e.g. Das,

The first two authors contributed equally.

Sanjay Jain

sjain4@scu.edu

Anil Nair

anair@odu.edu

David Ahlstrom

ahlstrom@baf.msmail.cuhk.edu.hk

1 Department of Management, Leavey School of Business, Santa Clara University, 500 El Camino Real, Santa Clara, CA 95053, USA

2 Department of Management, Old Dominion University, 2030 Constant Hall, Norfolk, VA 23529, USA

3 Department of Management, CUHK Business School, The Chinese University of Hong Kong, Shatin, NT, Hong Kong 
2000; Nilekani, 2008; Chandler \& Zainulbhai, 2013; Sharma, 2015) —all of these constituting the first draft of this exciting phase in India's development.

A number of researchers have turned their attention to understanding various interesting features of the Indian business scene. These include relatively new developments such as the emergence of the domestic software services (Arora, Arunachalam, Asundi, \& Fernandes, 2001; Garud, Kumaraswamy, \& Sambamurthy, 2006), the pharmaceutical sector (Chittoor, Sarkar, Ray, \& Aulakh, 2009), and the location of strategically significant R\&D centers in India by multinational firms (Asakawa \& Som, 2008; Tellis, Prabhu, Chandy, \& Eisengerich, 2013). In addition, research is also taking a renewed look at long-existing phenomena such as the ubiquitous presence of family-based business groups in India (Khanna \& Palepu, 2000). More recently, some researchers have also started to turn their attention to exploring whether certain business strategies and practices are uniquely Indian, and if these can be ported to other contexts (Cappelli, Singh, Singh, \& Useem, 2010; Govindarajan \& Trimble, 2013; Khanna, 2007; Prahalad \& Mashelkar, 2010; Radjou, Prabhu, \& Ahuja, 2012). These seemingly unique Indian approaches have been articulated in terminology such as the "Indian Way" (Cappelli et al., 2010), "jugaad innovation" (Prabhu \& Jain, 2015; Radjou et al., 2012), "Gandhian innovation" (Prahalad \& Mashelkar, 2010) and "reverse innovation" (Govindarajan \& Trimble, 2013), among others. Taken together, these strands of scholarship reflect the beginnings of a vibrant and insightful set of conversations that can enable us to make deeper sense of the remarkable socio-economic changes taking place in India as well as enhance existing theories of strategy and organizations (Bruton, Ahlstrom, \& Obloj, 2008; Peng, Wang, \& Jiang, 2008; Young, Tsai, Wang, Liu, \& Ahlstrom, 2014).

In this spirit, the editors of $A P J M$ expressed the need for developing a deeper understanding of two closely related academic domains that are vital to India's sustained economic growth: innovation and entrepreneurship (Aghion \& Howitt, 1992; Ahlstrom, 2010, 2015; Alvarez, Barney, \& Newman, 2015; Radjou et al., 2012). In 2012, the then Editor-in Chief of APJM David Ahlstrom started assembling a team of scholars, including Senior Editor Anil Nair and Professor Sanjay Jain, who had an interest in India as well as in innovation and entrepreneurship to edit this Special Issue. Announcements for submission of manuscripts related to this topic were sent out on the Academy of Management (AOM) and Asia Academy of Management (AAOM) list-servers. We received more than 50 manuscripts in response to this call for papers. The review process finally led to selection of the papers you find in this issue. Several other papers that had good promise and potential do not appear in this Special Issue because the authors were unable to submit revisions on time. The five papers that do appear in this Special Issue, including this introductory paper, provide consolidation and expansion of the themes identified in prior work related to entrepreneurship and innovation within the Indian context.

The article by Nair, Guldiken, Pezeshkan, and Fainschmidt (2015) offers a comprehensive review of the expanding literature on innovation in India. As highlighted in the review, the literature on innovation in India is fairly comprehensive and has taken on a vibrancy in recently years as India has reformed and pursued faster economic growth (Chari \& Banalieva, 2015). The authors suggest that this research often did not get published in some of the top tier management and innovation journals (usually from the United States or the United Kingdom) because of minimal interest in India or because 
the studies did not adopt the positivistic empirical methodology favored by such journals. Many of the firm-level studies they found adopted a case study approach to either apply foreign theories in the Indian context, or explain processes that may be unique to Indian innovation; however, the macro country-level studies on patents were empirical and involved statistical analysis.

Nair and colleagues also describe the arc Indian innovation studies have followed in past years. Earlier studies largely examined the role of government institutions on innovation, while more recent studies have started examining the role of MNEs and liberalization on innovation. They further point out that the state of flux that India is in now with the gradual unfolding of liberalization across different sectors of the economy offers a rich eco-system from which to study the factors and contingencies that impact innovation.

Related to the above theme, the paper by Ashwin, Krishnan, and George (2015) examines the role of family ownership, business group membership, and industry characteristics on innovation. Thus, this is a study that captures some of the uniqueness of the Indian business setting (Ahlstrom, Chen, \& Yeh, 2010). Several scholars have noted the importance of family firms (van Essen, Carney, Gedajlovic, \& Heugens, 2015), and business groups (Carney, 2008) and their extensive participation in the Indian economy (Gedajlovic, Carney, Chrisman, \& Kellermanns, 2012). While these organizational forms have traditionally played significant roles in the Indian economy, they are now subject to several internal and external cross-currents that were unleashed by the 1991 economic reforms (Chari \& Banalieva, 2015). These include the arrival of MNEs from Asia, Europe, and North America with varying competitive priorities, strategies, and resources along with the threats/opportunities they pose; the creation of opportunities in markets abroad; and internally, the rise of professionally and/or foreign trained children into upper management ranks (Au, Craig, \& Ramachandran, 2011; Hoskisson, Wright, Filatotchev, \& Peng, 2013; Lu, Au, Peng, \& Xu, 2013). Using the pharmaceutical industry as their setting, Ashwin et al. (2015) adopt stewardship and agency theories to develop and test hypotheses about the impact of family ownership on R\&D and innovation outcomes. They find that family-owned businesses adopted a stewardship model in an environment characterized by opportunities.

The paper by Prabhu and Jain (2015) addresses issues that have generated considerable interest among scholars and practitioners in recent times, that is, the notions of jugaad and social entrepreneurship (e.g., Radjou et al., 2012). Despite India's economic growth, a considerable proportion of its population still lives in conditions of poverty that is perpetuated by difficult socio-political and institutional conditions (Banerjee \& Duflo, 2011; Bruton, Ahlstrom, \& Si, 2015). Providing these underserved communities with the basic necessities - such as energy, health, education, and communicationinvolves, on the business side, developing products and services as well as associated business models and organizational forms that require high levels of ingenuity and empathy (Ahlstrom, 2010; Chari \& Banalieva, 2015). At another level, years of socialist economic policies that limited competition and restricted access to technology created an environment of shortages and constraints - one in which resourcefulness became a necessity and a way of life. In response, numerous organizations operating in India - both formal and informal - have demonstrated an uncanny ability to engage in "jugaad" (pronounced ju-gaar) — which, roughly translated from its Hindi origins, means "making things happen" (Radjou et al., 2012). In their article, Prabhu and Jain document instances of jugaad innovation, provide a theoretical specification for this 
construct, and offer an agenda for future research on this topic. In doing so, they endeavor to take jugaad beyond mere detailed description and towards the subject of more systematic study - a move that in effect, foreshadows the need for developing more culturally informed theories of innovation and entrepreneurship that emphasize aspects of non-Western, indigenous approaches to management (Li, 2012).

Prasantham and Dhanaraj (2015) address an issue that is very crucial to entrepreneurial new ventures in emerging economies: How to quickly internationalize? International new ventures (INVs) have generated considerable interest among international business (IB) scholars, with the pace, direction, and intensity of internationalization attracting research attention in recent years (Oviatt \& McDougall, 1994, 2005; Rialp, Rialp, \& Knight, 2005). Prasantham and Dhanaraj examine the internationalization process by investigating how the alliancing of new ventures impact their internationalization. Specifically, they examine how ties with MNEs and local SMEs impact new ventures' expansion abroad. Employing a multi-method study to investigate the phenomenon, the paper uses a longitudinal case analysis and a survey of 102 firms. They find a positive relationship between local MNE ties and internationalization capability, but also find that ties with MNEs are necessary yet not sufficient for new ventures to internationalize; they require managerial action to exploit the knowledge acquired. In addition to the interesting results, the study reveals the advantages of adopting a multi-method approach in generating unique insights about phenomenon.

The papers published in this Special Issue capture only a slice of the fascinating work now in progress in Indian innovation and entrepreneurship (e.g., George, RaoNicholson, Corbishley, \& Bansal, 2015; Jain \& Sharma, 2013; Kumar, 2007; Nair \& Ahlstrom, 2003). The papers in this Special Issue also provoke a number of additional research questions and directions. A number of emerging phenomena-the formation of multiple innovation clusters in the country, the explosion in mobile commerce based start-ups, a growing alternative energy sector, virtual and diverse work teams, social entrepreneurship, and new business models and organizational forms - represent exciting avenues for future research (Kleiner, 2014; Maheshwari \& Ahlstrom, 2004; Nair, Ahlstrom, \& Filer, 2007). Moreover, the growing presence of multinationals, an engaged Indian diaspora, and a number of recent exemplars (entrepreneurs and innovators) who have captured the country's imagination - have all contributed to the growing ethos of innovation and entrepreneurship that now pervades the country (Jain \& Sharma, 2013; Khanna, 2007; Kumar \& Puranam, 2012; Radjou et al., 2012; Varma, 2004). This is particularly true in certain technologically vibrant regions such as Bangalore in the south (Nair et al., 2007), further suggesting the need for understanding regional differences in large, diverse countries such as India (cf. Gong, Chow, \& Ahlstrom, 2011).

These developments are resulting in unique approaches - sometimes indigenous but often hybrid - for engaging in innovation and entrepreneurship. A deeper understanding of these phenomena should make for insightful extensions and reformulations of our existing theories in these domains (cf. Ahlstrom, Bruton, \& Lui, 2000). Supporting these endeavors in recent years is an exponential growth in underlying research capacity, both in terms of faculty and doctoral students interested in examining these phenomena. A particularly noteworthy development along these lines is the significant expansion in doctoral programs - and associated research related activity such as conferences and workshops - that is now unfolding within India's leading business schools and is likely to contribute to an increase in rigorous and relevant scholarship in 
these domains going forward. As we wrap up this Special Issue on India for Asia Pacific Journal of Management, we feel the future of innovation and entrepreneurship research in India is vibrant. We believe that scholarship in these domains can serve a vital function in informing practitioners, policy makers and citizens as to the role that innovation and entrepreneurial activity play in fostering socio-political and economic change in the Indian context and other emerging economy contexts (McCloskey, 2013; Wang, Ahlstrom, Nair, \& Hang, 2008). Along these lines, we hope that this Special Issue both signals the importance of these research trajectories as well as fosters substantial scholarship in these areas going forward.

\section{References}

Aghion, P., \& Howitt, P. 1992. A model of growth through creative destruction. Econometrica, 60(2): 323-351.

Ahlstrom, D. 2010. Innovation and growth: How business contributes to society. Academy of Management Perspectives, 24(3): 11-24.

Ahlstrom, D. 2015. Innovation and growth in emerging economies. In Austrian Council for Research and Technology Development (Ed.). Designing the future: Economic, societal, and political dimensions of innovation: 353-387. Vienna: Echomedia.

Ahlstrom, D., Bruton, G. D., \& Lui, S. S. Y. 2000. Navigating China's changing economy: Strategies for private firms. Business Horizons, 43(1): 5-15.

Ahlstrom, D., Chen, S., \& Yeh, K. S. 2010. Managing in ethnic Chinese communities: Culture, institutions, and context. Asia Pacific Journal of Management, 27(3): 341-354.

Alvarez, S. A., Barney, J. B., \& Newman, A. M. 2015. The poverty problem and the industrialization solution. Asia Pacific Journal of Management, 32(1): 23-37.

Arora, A., Arunachalam, V. S., Asundi, J., \& Fernandes, R. 2001. The Indian software services industry. Research Policy, 30(8): 1267-1287.

Asakawa, K., \& Som, A. 2008. Internationalization of R\&D in China and India: Conventional wisdom versus reality. Asia Pacific Journal of Management, 25(3): 375-394.

Ashwin, A. S., Krishnan, R. T., \& George, R. 2015. Family firms in India: Family involvement, agency, stewardship, and innovation. Asia Pacific Journal of Management. This issue.

Au, K., Craig, J. B., \& Ramachandran, K. 2011. Introduction. In K. Au, J. B. Craig, \& K. Ramachandran (Eds.). Family enterprise in the Asia Pacific: Exploring transgenerational entrepreneurship in family firms: 1-20. Cheltenham: Edward Elgar.

Banerjee, A. V., \& Duflo, E. 2011. Poor economics: A radical rethinking of the way to fightglobal poverty. New York: Public Affairs.

Bardhan, P. 1994. Comment on 'The impact of constitutions on economic performance' by Elster. Proceedings of the World Bank Annual Conference on Development Economics: 232-235.

Baumol, W. J., Litan, R. E., \& Schramm, C. J. 2009. Good capitalism, bad capitalism, and the economics of growth and prosperity. New Haven: Yale University Press.

Bruton, G. D., Ahlstrom, D., \& Obloj, K. 2008. Entrepreneurship in emerging economies: Where are we today and where should the research go in the future?. Entrepreneurship: Theory and Practice, 32(1): 1-14.

Bruton, G. D., Ahlstrom, D., \& Si, S. 2015. Entrepreneurship, poverty, and Asia: Moving beyond subsistence entrepreneurship. Asia Pacific Journal of Management, 32(1): 1-22.

Cappelli, P., Singh, H., Singh, J., \& Useem, M. 2010. The India way: Lessons for the U.S. Academy of Management Perspectives, 24(2): 6-24.

Carney, M. 2008. The many futures of Asian business groups. Asia Pacific Journal of Management, 25(4): 595-613.

Chandler, C., \& Zainulbhai, A. 2013. Reimagining India: Unlocking the power of Asia's next superpower. New York: Simon \& Schuster.

Chari, M. D. R., \& Banalieva, E. R. 2015. How do pro-market reforms impact firm profitability? The case of India under reform. Journal of World Business, 50(2): 357-367.

Chittoor, R., Sarkar, M. B., Ray, S., \& Aulakh, P. S. 2009. Third-world copycats to emerging multinationals: Institutional changes and organizational transformation in the Indian pharmaceutical industry. Organization Science, 20(1): 187-205. 
Das, G. 2000. India unbound: The social and economic revolution from independence to the global information age. New York: Random House.

Garud, R., Kumaraswamy, A., \& Sambamurthy, V. 2006. Emergent by design: Performance and transformation at Infosys Technologies. Organization Science, 17(2): 277-286.

Gedajlovic, E., Carney, M., Chrisman, J. J., \& Kellermanns, F. W. 2012. The adolescence of family firm research: Taking stock and planning for the future. Journal of Management, 38(4): 1010-1037.

George, G., Rao-Nicholson, R., Corbishley, C., \& Bansal, R. 2015. Institutional entrepreneurship, governance, and poverty: Insights from emergency medical response services in India. Asia Pacific Journal of Management, 32(1): 39-65.

Gong, Y., Chow, I. H.-s., \& Ahlstrom, D. 2011. Cultural diversity in China: Dialect, job embeddedness, and turnover. Asia Pacific Journal of Management, 28(2): 221-238.

Govindarajan, V., \& Trimble, C. 2013. Reverse innovation: Create far from home, win everywhere. Boston: Harvard Business Press.

Hoskisson, R., Wright, M., Filatotchev, I., \& Peng, M. W. 2013. Emerging multinationals from mid-range economies: The influence of institutions and factor markets. Journal of Management Studies, 50(7): 1295-1321.

Jain, S., \& Sharma, D. 2013. Institutional logic migration and industry evolution in emerging economies: The case of telephony in India. Strategic Entrepreneurship Journal, 7(3): 252-271.

Khanna, T. 2007. Billions of entrepreneurs: How China and India are reshaping their futures and yours. Boston: Harvard Business School Publishing.

Khanna, T., \& Palepu, K. 2000. Is group affiliation profitable in emerging markets? An analysis of diversified Indian business groups. Journal of Finance, 55(2): 867-891.

Kleiner, A. 2014. The thought leader: Thomas Malone. Strategy+Business, 75(Summer): 1-9.

Kumar, S. 2007. Kerala, India, A regional community-based palliative care model. Journal of Pain and Symptom Management, 33(5): 623-627.

Kumar, N., \& Puranam, P. 2012. India inside: The emerging innovation challenge to the West. Boston: Harvard Business Press.

Li, P. P. 2012. Toward an integrative framework of indigenous research: The geocentric implications of YinYang balance. Asia Pacific Journal of Management, 29(4): 849-872.

Lu, Y., Au, K., Peng, M. W., \& Xu, E. 2013. Strategic management in private and family business. Asia Pacific Journal of Management, 30(3): 633-639.

Maheshwari, S. K., \& Ahlstrom, D. 2004. Turning around a state owned enterprise: The case of Scooters India Limited. Asia Pacific Journal of Management, 21(3/4): 75-101.

McCloskey, D. N. 2010. Bourgeois dignity: Why economics can't explain the modern world. Chicago: University of Chicago Press.

McCloskey, D. N. 2013. Tunzelmann, Schumpeter, and the hockey stick. Research Policy, 42(10): 17061715.

Nair, A., \& Ahlstrom, D. 2003. Delayed creative destruction and the coexistence of technologies. Journal of Engineering and Technology Management, 20(4): 345-365.

Nair, A., Ahlstrom, D., \& Filer, L. 2007. Localized advantage in a global economy: The case of Bangalore. Thunderbird International Business Review, 49(5): 591-618.

Nair, A., Guldiken, O., Pezeshkan, A., \& Fainschmidt, S. 2015. Indian innovation research: review and future directions. Asia Pacific Journal of Management. This issue.

Nilekani, N. 2008. Imagining India: The idea of a renewed nation. New York: Penguin.

Oviatt, B. M., \& McDougall, P. P. 1994. Toward a theory of international new ventures. Journal of International Business Studies, 25(1): 45-64.

Oviatt, B. M., \& McDougall, P. P. 2005. Defining international entrepreneurship and modeling the speed of internationalization. Entrepreneurship: Theory and Practice, 29(5): 537-553.

Peng, M. W., Wang, D. Y. L., \& Jiang, Y. 2008. An institution-based view of international business strategy: A focus on emerging economies. Journal of International Business Studies, 39(5): 920-936.

Prabhu, J., \& Jain, S. 2015. Innovation and entrepreneurship in India: Understanding Jugaad. Asia Pacific Journal of Management. This issue.

Prahalad, C. K., \& Mashelkar, R. A. 2010. Innovation's holy grail. Harvard Business Review, July-August: $132-141$.

Prasantham, S., \& Dhanaraj, C. 2015. MNE ties and new venture internationalization: Exploratory insights from India. Asia Pacific Journal of Management. This issue.

Radjou, N., Prabhu, J., \& Ahuja, S. 2012. Jugaad innovation: Think frugal, be flexible, generate breakthrough growth. San Francisco: Jossey Bass. 
Rialp, A., Rialp, J., \& Knight, G. A. 2005. The phenomenon of early internationalizing firms: What do we know after a decade (1993-2003) of scientific inquiry?. International Business Review, 14(2): 147-166.

Sharma, M. S. 2015. Restart: The last chance for the Indian economy. Gurgaon: Vintage Books.

Sivaraman, B. 1991. Bitter sweet: Governance of India in transition. New Delhi: Ashish Publishing House.

Tellis, G., Prabhu, J., Chandy, R., \& Eisengerich, A. 2013. Competing for the future: Patterns in the global location of R\&D centers by the world's largest firms. ISBM report no. 06-2008, The Pennsylvania State University.

van Essen, M., Carney, M., Gedajlovic, E. R., \& Heugens, P. P. M. A. R. 2015. How does family control influence firm strategy and performance? A meta-analysis of US publicly listed firms. Corporate Governance: An International Review, 23(1): 3-24.

Varma, P. 2004. Being Indian: The truth about why the 21st century will be India's. New Delhi: Penguin.

Wang, L. C., Ahlstrom, D., Nair, A., \& Hang, R. Z. 2008. Creating globally competitive and innovative products: China's next Olympic challenge. SAM Advanced Management Journal, 73(3): 4-14.

Young, M. N., Tsai, T., Wang, X., Liu, S., \& Ahlstrom, D. 2014. Strategy in emerging economies and the theory of the firm. Asia Pacific Journal of Management, 31(2): 331-354.

Sanjay Jain (PhD, New York University) is an assistant professor at Santa Clara University. His research interests include the emergence of innovations and industries, developing markets for underserved communities, technology entrepreneurship, and qualitative methodology. Professor Jain has published articles in journals such as the Academy of Management Journal, Research Policy, Organization Studies, Strategic Entrepreneurship Journal, and Industrial and Corporate Change. He is currently on the editorial boards of Organization Science and Asia Pacific Journal of Management.

Anil Nair ( $\mathrm{PhD}$, New York University) is a professor at the Strome College of Business, Old Dominion University. His research interests include competitive strategy, risk, innovation and entrepreneurship. He has published over two dozen articles in journals such as Strategic Management Journal, Management International Review, Long Range Planning, and Asia Pacific Journal of Management.

David Ahlstrom ( $\mathrm{PhD}$, New York University) is a professor at The Chinese University of Hong Kong. He obtained his $\mathrm{PhD}$ in Management and International Business after working for nearly a decade in government and industry, including several years in the computer field. His research interests include managing in Asia, innovation and entrepreneurship, decision-making, and management and organizational history. Professor Ahlstrom has published over 90 peer-reviewed articles in journals such as the Strategic Management Journal, Academy of Management Review, Journal of International Business Studies, Journal of Management Studies, Journal of Business Venturing, Entrepreneurship: Theory and Practice, Academy of Management Perspectives, and the Brown Journal of World Affairs. His work has also appeared multiple times in The Wall Street Journal. Professor Ahlstrom co-authored the textbook International Management: Strategy and Culture in the Emerging World and guest edited two Special Issues of Entrepreneurship: Theory \& Practice. Professor Ahlstrom has also guest edited three Special Issues of Asia Pacific Journal of Management: Turnaround in Asia (in 2004), Managing in Ethnic Chinese Communities (in 2010), and Asia \& Poverty: Closing the Great Divide through Entrepreneurship \& Innovation (in 2015). He was Senior Editor of APJM 2007-2009, before serving as APJM's Editor-in-Chief from 2010 to 2012, and is currently a Consulting Editor. Professor Ahlstrom is also a Senior Editor of Journal of World Business. 